\title{
FATTY ACID BIOSYNTHESIS IN THE TESTIS OF THE HUMAN FETUS DURING THE FIRST TRIMESTER
}

\author{
B. AHLUWALIA, J. WILLIAMS AND P. VERMA
}

\author{
Endocrine Research Laboratory, Departments of Medicine \\ and Obstetrics and Gynecology, Howard University College of Medicine, \\ Washington, D.C. 20059, U.S.A.
}

\section{(Received 4th December 1974)}

Lipid biosynthesis in the adult testis in several species has been reported (Davis, Bridges \& Coniglio, 1966; Bridges \& Coniglio, 1970; Carpenter, 1971; Ayala, Gaspar, Brenner, Peluffo \& Kunau, 1973). Similar studies in the fetal testis are not available. The purpose of this study was to investigate the ability of the testis of the human fetus during the first trimester to synthesize fatty acids from labelled substrates.

The compounds purchased from the Applied Science Laboratory, State College, Pennsylvania, were $99 \%$ pure $\left[1-{ }^{14} \mathrm{C}\right]$ linoleic acid (all cis; sp. act., $52.5 \mathrm{mCi} / \mathrm{mmol}$ ) and $99 \%$ pure $\left[1-{ }^{14} \mathrm{C}\right]$ arachidonic acid (all cis; sp. act., $52.5 \mathrm{mCi} / \mathrm{mmol}) ;\left[1,2-{ }^{14} \mathrm{C}\right]$ sodium acetate $($ sp. act., $54 \mathrm{mCi} / \mathrm{mmol}$ ) was received from New England Nuclear Corp., Boston, Massachusetts.

Undamaged abortuses were obtained from the abortion clinic at Freedmen's Hospital, Howard University, and the ages of the fetuses were determined from crown-rump measurement. Abortions were performed by injection of hypertonic saline solution $(20 \%)$ into the amniotic fluid, usually between 12 and 16 weeks of gestation, and generally occurred within 10 to $12 \mathrm{hr}$ after injection. The testes were carefully removed, cleaned and weighed, and a portion of the tissue was used for histological examination in initial studies to confirm the characteristics of a normal human fetal testis. Histological examination of the fetal testes at 12 to 16 weeks of gestation showed well-developed interstitial cells and sex cords.

Every effort was made to initiate incubation studies within a few hours after abortion; on occasion, however, the testes were removed, cleaned, weighed and stored at $-70^{\circ} \mathrm{C}$ for later analysis. We have observed no significant differences in fatty acid biosynthesis in tissues stored for up to 60 days at $-70^{\circ} \mathrm{G}$.

In each incubation study, $5 \mu \mathrm{Ci}$ linoleic or arachidonic acid or $40 \mu \mathrm{Ci}$ sodium acetate were used. Linoleic or arachidonic acid was first mixed in a small quantity of propylene glycol and then added to the incubation media. Sodium acetate was added directly to the media. The incubation mixture contained in $3 \mathrm{ml}$ of $0.15 \mathrm{M}-\mathrm{KCl}$ and $0.25 \mathrm{M}$-sucrose: $4 \mu \mathrm{mol} \mathrm{ATP,} 2.5 \mu \mathrm{mol} \mathrm{NADH}, 15$ $\mu \mathrm{mol} \mathrm{MgCl}_{2}, 4.5 \mu \mathrm{mol}$ glutathione, $1 \mu \mathrm{mol}$ nicotinamide, $125 \mu \mathrm{mol} \mathrm{NaF}, 125$ $\mu$ mol phosphate buffer at $\mathrm{pH} 7$ (Ayala et al., 1973). All incubations were performed at $37^{\circ} \mathrm{C}$ for $3 \mathrm{hr}$. A preliminary study was conducted to determine the optimum incorporation of radioactivity in total fatty acids at various incubation 
times. The results showed that the maximum amount of radioactivity in total fatty acids was obtained following incubation for $3 \mathrm{hr}$. The incubation was terminated by the addition of $1 \mathrm{ml} \mathrm{of} 10 \% \mathrm{KOH}$ in ethanol. The mixture was saponified in an atmosphere of nitrogen, and non-saponifiable material was removed by extraction with petroleum ether. Total fatty acids were extracted from the acidified solution with petroleum ether and methylated according to the method of Metcalfe \& Schmitz (1961).

Methyl esters of individual fatty acids were chromatographed in a Beckman GC-65 gas-liquid chromatograph with a hydrogen flame detector. A stream splitter between the column and detector allowed $10 \%$ of the effluent stream to go to the detector and $90 \%$ to an automatic collector. The column was 183 $\times 0.62 \mathrm{~cm}$ i.d. and was packed with Gas Chrom P containing $16 \%$ EGS-X (Applied Science Laboratory, Inc., State College, Pennsylvania). The column temperature was $185^{\circ} \mathrm{C}$, and the gas flow rate was $30 \mathrm{ml} / \mathrm{min}$. The methyl esters were collected in cartridges packed with silicone-coated anthracene for direct determination of ${ }^{14} \mathrm{C}$ in a Beckman LS-250 liquid scintillation spectrometer with a counting efficiency of $90 \%$ for ${ }^{14} \mathrm{C}$. The $\%$ composition of individual fatty acids was determined on the basis of the direct proportion of the peak areas measured by triangulation. A standard mixture of fatty acids (Applied Science Laboratory, Inc.) was used to identify the unknowns. Fatty acids for which standards were unavailable were tentatively identified from carbon numbers by plotting log retention time against chain length of degree of unsaturation (Holman \& Hofstetter, 1965). Internal standards were employed to confirm the tentative identification. To determine linearity of GLG, known standards of various concentrations were employed throughout the analysis.

If it is assumed that metabolism of $\left[1-{ }^{14} \mathrm{C}\right]$ acetate is a physiological pathway of new fatty acid biosynthesis, then it would appear that the fetal testis has developed a complete enzyme system to synthesize fatty acids in the first trimester (Table 1). The ability of first trimester fetal testes to elongate and desaturate fatty acids from linoleic or arachidonic acid is demonstrated (Table 1). Approximately $0.05 \%$ labelled acetate and $4.5 \%$ linoleic acid or arachidonic acid were incorporated into individual fatty acids. It is still not known, however, whether in the intact fetus the fatty acids are synthesized in situ in the testis or brought there after synthesis elsewhere. The development of the fetal gonads starts about the 4th week of gestation. Between 6 and 12 weeks of gestation, the testes are fully developed, and Leydig cells and immature Sertoli cells are very prominent (Lipsett \& Sherins, 1974); thus, the possibility of the fatty acid synthetase enzymes being located in any specific component in the testicular tissue in fetuses of 12 to 16 weeks of gestation is speculative. It is known, however, that the Leydig cells are most numerous in the fetal testis at 12 to 17 weeks of gestation (Rosemberg \& Paulsen, 1971). The ability of the fetal testis to synthesize androgens from acetate is known (Ahluwalia, Williams \& Verma, 1974), and $3 \beta$-hydroxysteroid dehydrogenase, a steroid biosynthetic enzyme, is present in these cells during fetal life (Gallegos, Pflaum \& Fernandez, 1959).

The similarity in the fatty acid composition of the human fetal testis (Table 1) and adult testis as reported by Bieri \& Prival (1965) is interesting. Quantita- 
tively, there are only minor differences. For example, there is slightly more C22:6 $63(8.5 \%)$ in the adult testis compared with the fetal testis $(5.4 \%)$ and less $18: 3 \omega 3(0.7 \%)$ compared with the fetal testis $(1.6 \%)$. From the results of our studies and those of Bieri \& Prival (1965), it can be concluded that specificity in the fatty acid pattern in an organ such as the testis is determined genetically during fetal life and dietary effects during adult life under normal conditions are minor. The findings reported by Grogan, Coniglio \& Rhamy (1973) of relatively small amounts of $22: 5 \omega 6$ and large amounts of $22: 6 \omega 3$ in adult human testes are similar to our findings in human fetal testes (Table 1).

Table 1. The incorporation of ${ }^{14} \mathrm{C}$ into individual fatty acids following incubation of human fetal testicular tissue with radiolabelled substrate

\begin{tabular}{|c|c|c|c|c|}
\hline \multirow[b]{2}{*}{ Fatty acids } & \multirow{2}{*}{$\begin{array}{c}\% \text { Total fatty acids } \\
\begin{array}{c}(\text { Mean } \pm S . E .) \\
(4)\end{array}\end{array}$} & \multicolumn{3}{|c|}{$\%$ Incorporation of total radioactivity from: } \\
\hline & & $\begin{array}{l}\text { Sodium acetate } \\
\text { (2) }\end{array}$ & $\begin{array}{l}\text { Linoleic acid } \\
\text { (2) }\end{array}$ & $\begin{array}{c}\text { Arachidonic acid } \\
\text { (2) }\end{array}$ \\
\hline $\begin{array}{l}14: 0 \\
16: 0 \\
18: 0 \\
18: 1 \omega 9 \\
18: 2 \omega 6 \\
18: 3 \omega 3 \\
20: 3 \omega 6 \\
20: 4 \omega 6 \\
22: 4 \omega 6 \\
22: 5 \omega 6 \\
22: 6 \omega 3\end{array}$ & $\begin{array}{r}1.0 \pm 0.4 \\
32.0 \pm 4.9 \\
20.0 \pm 3.5 \\
11.9 \pm 2.9 \\
3.8 \pm 1.7 \\
1.6 \pm 0.8 \\
1.0 \pm 0.6 \\
18.8 \pm 5.6 \\
1.6 \pm 0.7 \\
0.8 \pm 0.2 \\
5.4 \pm 1.2\end{array}$ & $\begin{array}{r}6 \cdot 5 \\
39 \cdot 5 \\
3 \cdot 3 \\
3 \cdot 9 \\
4 \cdot 0 \\
2 \cdot 1 \\
2 \cdot 0 \\
1 \cdot 8 \\
0 \cdot 6 \\
0 \cdot 2 \\
0 \cdot 2\end{array}$ & $\begin{array}{r}1.2 \\
6 \cdot 0 \\
3 \cdot 0 \\
2 \cdot 4 \\
78 \cdot 0 \\
1 \cdot 8 \\
3 \cdot 0 \\
2 \cdot 0 \\
0 \cdot 8 \\
0.2 \\
0.5\end{array}$ & $\begin{array}{r}0 \cdot 3 \\
2 \cdot 4 \\
1 \cdot 1 \\
0 \cdot 2 \\
1.9 \\
2 \cdot 4 \\
2 \cdot 7 \\
82 \cdot 5 \\
1 \cdot 0 \\
0.9 \\
0.7\end{array}$ \\
\hline
\end{tabular}

Figures within parentheses represent the number of samples analysed. Testicular tissue $(250 \mathrm{mg})$ was incubated with either $40 \mu \mathrm{Ci}$ sodium acetate or $5 \mu \mathrm{Gi}$ linoleic or arachidonic acid. The fatty acids were isolated on gasliquid radiochromatography and the \% incorporation in individual fatty acids was determined. Identification of the fatty acids was based on authentic standards wherever available and on the carbon number.

The important conclusion of these studies lies in the observation that human fetal testes develop enzyme systems very early in intrauterine life and, at least qualitatively, the fatty acids appear to be similar to those in adult human testes. Although fetal testes can utilize acetate or linoleic acid as substrates to synthesize and elongate chain length, purely on the basis of biochemical economy the use of preformed fatty acids emanating from the placenta would be a more efficient precursor than synthesis of fatty acids de novo. The transport of fatty acids across the placental membrane has been studied experimentally in a number of mammals though not in man. Popjak \& Beckham (1950) reported that in experimental animals lipids were mainly synthesized from simple components within the trophoblast cells and transported to the fetus during the first 6 months of gestation.

Supported in part by National Institutes of Health research grant 3S01 RR 05361-12S1. 


\section{REFERENGES}

Amluwalia, B., Williams, J. \& Verma, P. (1974) In vitro testosterone biosynthesis in the human fetal testis. II. Stimulation by cyclic AMP and human chorionic gonadotropin (hGG). Endocrinology, 95, 1411-1415.

Ayal.a, S., Gaspar, G., Brenner, R. R., Peluufro, R. O. \& Kunau, W. (1973) Fate of linoleic, arachidonic and docosa 7,10,13,16-tetraenoic acids in rat testicles. F. Lipid Res. 14, 296-305.

Bierr, J. G. \& Prrvat, E. L. (1965) Lipid composition of testes from various species. Comp. Biochem. Physiol. 15, 275-282.

Brmges, R. B. \& Conicuro, J. G. (1970) The biosynthesis of $\Delta 9,12,15,18$-tetracosatetraenoic and $\Delta 6,9,12,15,18$-tetracosapentaenoic acids by rat testes. $\mathcal{F}$. biol. Chem. 245, 46-99.

CARpenter, M. (1971) The lipid composition of maturing rat testes. The effect of $\alpha$-tocopherol. Biochim. biophys. Acta, 231, 52-79.

Davis, J. T., Brmges, R. B. \& Coniglio, J. G. (1966) Ghanges in the liquid composition of the maturing rat testis. Biochem. 3. 98, 342-346.

Gallegos, R., Prlaum, P. E. \& Fernandez, J. A. (1959) Biologia de los anexos fetalis. La Semana Med. 114, 311-323.

Grogan, W. M., Fr, Goniglio, J. G. \& Rhamy, R. K. (1973) Identification of some polyenoic acids isolated from human testicular tissue. Lipids, 8, 480-481.

Holman, R. T. \& Hofstetrer, H. H. (1965) The fatty acid composition of the lipids from bovine and porcine reproductive tissue. $\mathcal{F}$. Am. Oil Chem. Soc. 42, 540-544.

LipsetT, M. B. \& Sherins, R. J. (1974) The testis. In Textbook of Medicine, pp. 1553-1584. Eds. P. Bondy and L. Rosenberg. W. B. Saunders, Philadelphia.

Metcalfe, L. D. \& Schmitz, A. A. (1961) The rapid preparation of fatty acid esters for gas chromatographic analysis. Analyt. Chem. 33, 363-364.

Popjak, G. \& Beckman, M. L. (1950) Are phospholipids transmitted through the placenta? Biochem. $\mathcal{F}$. 46, 99-103.

Rosemberg, E. \& Paulsen, G. A. (1971) The Human Testis, pp. 23-24. Plenum Press, New York. 